\title{
新しいエ学教育を目指して 北海道大学工学部の将来構想
}

"Toward the New Development of Engineering Education,

The Prospective Conception at Faculty of Engineering, Hokkaido University"

\section{柴 田 拓 二 \\ Takuji SHIBATA}

大学改革と工学教育, 現在社会における工学の役割, 現在の工学教育の閉塞と新 たな展開の必要性について述べ, 北海道大学工学部の将来構想を紹介する。 キーワード：工学の新なな認識・専門性の再構築・大綱化と工学教育

The characteristics of engineering education in the due reformation of universities, the tasks of the engineering profession in the present society and the necessity of new development of engineering education are discussed, and the prospective conception for the reformation of engineering education at Hokkaido University is introduced.

\section{1.はじめに}

大学改革の諭議は, 新制大学発足後, 寄せては返す波 のように繰り返し行われてきたが, 今日ほどの高波とな って広く各界の関心を引き，マスコミにも再々取上げら れたことはなかったと思われる。

マスコミ等で多くの論者が指摘する今日の大学問題は, おおむね次のような認識によっている。

(1) わが国の初等・中等教育は国際的にも優れているが, 激しい受験戦争を通過した後の大学教育はレベルが低 く, 教師も学生も意欲を欠き, 大学はレジャーランド 化している。

（2）大学人は, 社会情勢の変化に関わりなく, 競争原理 の働かない硬直化した組織機構内に安住しており, 自 らを变革する能力を持っていない。

（3）わが国の科学技術研究は, 欧米の基礎研究の成果を 土台にしての応用研究が多く, 独創的な研究が少ない。 今, わが国も基礎研究に重点的に投資して，その飛躍 的な振興を図り, 国際的貢献を強化して諸外国の「た だ乗り」批判を克服しなければならない。
（4）国立大学の施設・設備の老朽化が著しく, 海外の諸 大学ならびに国内の企業研究所に比べて, 顕著な機能 低下を生じている。

(5) 平成 4 年現在 205 万人の 18 歳人口が, 平成 12 年 (西暦 2000年)には151万人になり，その後も減少を続ける状 況の下で, 改革を意る魅力のない大学は淘汰される。 いまこそ生き残りを馝けて，個性的な特色のある大学 造りに努めるべき時である。

以上のような認識は，すべでが個々の大学に必ずしも 当てはまるとはいえないにしても，一般論としては大学 の現在の危機的状況を反映しているものといえよう。視 点を変えていえば，現在 4 年制大学のみでも同世代人口 の $26 \%$, 短大・高専・大学を合せて $38 \%$ 進学し, 人口 減があるにしても, さらに進学率の増進が見込まれる状 況下で, 大学一般を論ずることには無理があり, 各専門 分野について高等教育が担うべき社会的な役割を踏まえ ての諭議がより実践的であろう。

現在, 高等教育における工学系の学生数は，4 年制大 学学部で全数の約 $20 \%$, 短大で $5 \%$ あ゙あ, 多くの大学 論の視野の中には(とくに論者が文系の場合には), 工学 
系の教育研究の実態が入り難いことはやむを得ない。例 えば上記の(3)について，「基礎」とは理学分野であり, 工学すなわち応用ないしは利潤追求のための技術開発と する単純な論旨も少なくない。しかし，それがむしろ社 会一般の通念に近いとすれば，工学の側から現代社会に おける工学の使命掞よび教育研究の現状と問題点, 将来 に向けてのあるべき姿を積極的に社会に訴えて行かなけ ればならない。

\section{2. 現代社会における工学の役割}

一般に理系，あるいは理工系という表現が用いられ， 理学と工学とが同系の学術のように考えられることが多 いが，両者は基本的に動機と方法において異なるもので ある。理学は本来, 自然現象を観察し, 構成要因とそれ らの相互関係を明らかにして, 普遍的な支配法則を見出 そうとする純粋な知的欲求の上に成立しており，方法的 には主として分析的手法によっている。それは，もう一 冊のバイブルである自然を解読して, 神の摂理に近づこ うとすることと通じている。一方，工学は，より豊かで 安全・快適な衣食住を求䂗活の智恵から始まった人 間の自己拡大の手段としての技術が, 社会化され, 体系 化されてきたものであり，目的に対して適合するモノと システムを創出するための学術体系である。工学では, 設定された目的に対する, 可能性の追求, 選択, 要素の 総合, 機能の評価を手法とし, 理学とは異なる論理を構 成している。

工学は, 工業化社会において社会的生産と流通の基盤 として機能してきたが，今日ではあらゆる社会システム を構築し, 運営し, 維持するための基盤となっていて, 工業生産は当然であるが，その他すべての社会的営為が 工学的所産の上に成立している。

もちろん, 現代の工学は理学と分かちがたく結び付い ており，理学における成果を最大限に利用するが，工学 の学術的基盤が，理学に全的に包摂されているわけでは ない。逆に理学の目的科学化による工学への接近があり, 工学が理学的手法を包含しつつ発展しているといえる。

上述の「基礎研究」が外交交涉等の場で指摘されてい るいわゆる "generic technology”を指すのであれば, それは工学における共通基盤的な研究のことであり，工 学と理学その他の諸科学との接点に近い研究領域を指す ものである。したがって, 基礎研究すなわち理学, 工学 =応用研究という短絡しな割り切り方は誤りである。

工学のなかには,もともと, 国土計画・都市計画・地 域計画・都市設計・資源開発・エネルギー工学・環境工 学等の直接的に社会・経済・法律等の社会科学諸分野に
深く関わる領域があるが，すべての工学領域の発展が, 社会全般に重大な影響をもたらす可能性が高くなってい る現代社会においては，指導的立場に立つ工学専門家に は, 種々の社会的指標を読み取り, 人文・社会科学諸分 野の専門家との緊密な連携の下で，工学の調和ある発展 を主導することが求められる。

\section{3 . 現在の閉塞と新たな展開の必要性}

わが国の大学における工学教育は, 明治 3 年の工部省 の各尞を出発点とし, 今日の各大学工学部へと発展して きたが，学科の区分はそれぞれの時代の社会的要請に応 じて，工業分野分類におおむね対応するように設定され て今日に及んでいる。各学科には，それぞれの工業分野 の技術者教育に必要とされる一連の要素領域を担当する 講座をセットとして取り揃えられ，基本的に各学科がそ れぞれの専門技術教育を完結する相互に独立した專門教 育組織として運営されてきた。このため, 各学科には対 応する工業分野の特性によって独特の気風が醸成されて, 生産の場と教育研究の場を通して, 固有の技術文化圈が 形成されている。このような専門技術者養成の機構は, 各分野に高水準の技術者の厚い層を継続的に形成するこ とができた基盤であり，わが国の工業近代化の過程での 様々な蹉跌を克服して, 今日の経済発展を成し遂げてき た原動力となっていたものである。

しかし，「熟成度」の高い分野では，上記のような工 業分野対応の技術者教育の有効性がいまだ失われていな いものの，近年いずれの分野においても技術蓄積の著し い増大と膨大な情報の流れによって，学部教育段階で専 門技術教育の一応の完結を期することが極めて困難にな つてきており，学科における従来型の専門技術教育は, 焦点を絞りにくくなっている。このため, 学生の気質の 変化という要因もあるが，専門教育の内容の充実を目指 す教官側の熱意が，ややもすれば過密な教科目履修を課 すこととなり，学生の消化不良を招く結果となっている。

また，学科内では，当該分野の要素領域を分担する各 講座が，それぞれの要素領域ごとに異なる教育研究の内 容に責任を負っており，独立性の高い単位組織となって いる。講座は, 特定領域の学問の継承と成果の蓄積, 組 織の体系的運営の面で利点をもつが, 反面, 組織の規模 が小さいために，教育研究の展開が限定されがちであり， 人事の硬直化を招き易いなどの欠点も指摘されている。

工学部の一つの特色として, 講座の専門性を「対象物 の機能または研究方法」の観点から見ると, 同一学科内 よりもむしろ他学科に共通の専門性をもつ講座があるこ とが, 他の学部と様相の異なる点である。現在でも, こ 
れらの専門性を共有する講座の研究者が, 学科の枠を超 えて研究協力を進めている例は少なくないが，より広く 教育研究活動の自由な展開を図るためには, 組織体制上 の制約がある。

とくに, 大学院研究科が, 学部学科の組織機構をその まま利用して組織されている現状では，最先端の研究を 通じて教育研究指導を行う場である大学院の組織として は，学科の上に重ねられた専攻の機能には自ら限界があ る。上記のように, 学科内の講座群は, 要素領域の重複 を避けて構成されており, 各講座の行う最先端の研究と 教育は，学科二専攻内での講座の独立性を一層強調する ものとならざるを得ない。結果的に, 現在の大学院教育 では, 各講座の提示する特論をア・ラ・カルトとして羅 列している専攻のカリキュラムは副次的な課程となって, 実質上は，講座における研究指導を中心として展開され る幅の狭い領域の尃門家教育に限定されている。

今日, 工学技術の先端部分では, 旧来の分野分類の枠 組を超えて領域の複合・総合化が急速に進行しており， 現行の学部・大学院の組織・機構は, 次の世代の工学専 門家の教育の展開には適合しないことが明らかであり， 新たな理念で学部教育のあり方を見值し，また大学院の 明確な組織構造を構筑する必要がある。

\section{4. 北海道大学工学部の将来構想}

\section{1 新しい学部教育体制}

従来, 北海道大学では一般教育課程を文系 3 系, 理 系 3 系と水産学部・医学部・歯学部の各各部への 3 進 学課程からなる学生編成により構成し, 文系と理系に ついては, 2 年前期修了時に教養部が学部・学科への分 属を決定する方式が採られてきた。理 3 系は, 理 I : 数物系 (定員約700), 理II：化学系 (同約440), 理 III： 生物系(同約210)の構成で, 工学部へは理 I 系515名, 理II系166名, 理III系10名が各学科に分けられて進学 してくる。

この制度の長短については, 古くから多様な論議が 行われてきたが, 工学部としては, 近年の工学教育に 関わる諸課題の検討の中で, 入学時からの学部別学生 編成と, 一般教育・専門教育の楔型カリキュラム構成 を希望する意向が次第に強くなっていた。その主な理 由は, 学部 4 年間を一般教育課程と専門教育課程に横 割りして, 理念の異なる教育課程を短期間に分断して 積み重ねることによる不具合が，学生の専門分野への モティベーションの久落, 理系 3 系の分類の工学教育 への不適合, 教科内容の不整合による時間の浪費等の 形で顕在化してきたことである。
1 年半の一般教育課程では, 学生は進学先の専門分 野が不確定のまま, 広範な学部(理系では理・薬・工 - 農・獸医)の学科のうちから, 希望先への進学の可 能性を高めるために効率のよい科目履修に努めること になる。この課程履修を通じて, 教養を身につけるこ とを期待されているとすれば，すでに教養教育の理念 は破綻しているといわざるを得ない(これに対する反 論はある)。

理系の数物・化学・生物の系分類による基礎教育の 課程は，理学的発想に基づくもので，設定された目的 に対して広く可能性を追求しょうとする工学の立場か らは，限定的に過ぎるものである。

上記のような工学教育の観点から, 昨年 7 月の大学 設置基準の大綱化は，まことに歓迎すべきものであっ た。北海道大学では, 教養部が官制化されていなかっ たこともあって，他大学とはいささか趣きの異なる論 議もあったが, 4 年一貫の学部教育への転換が全学方針 として決定された。工学部としては, 学部教育を以下 のような方針に基づいて再構筑しようと考え, 具体的 な設計を進めている。

(1) 学部教育では大学院で高度の専門工学を学ぶため の確かな基盤を造らせるとともに，学部卒で就業す る者に，当該分野の専門技術者としてスタートする のに必要な基礎を着実に修得させることを目標とし， 併せて工学の多様な展開に対応できる基本的な理解 力と，他分野にも視野を広げることのできる素養を 身につけさせるものとする。

（2）一般教育は，社会的な視野の広さと国際性を養成 するために重要であるとともに，工学専門家にとっ ては，個人的教養に留まらず工学全般ならびに個々 の専門工学の社会的な機能を客観的に評価して, 調 和ある発展を図る上で, 人文科学・社会科学の基本 理念の理解は必須のものである。一般教育教科目を それぞれ適切な時期に，目的意識をもって自覚的に 学習できるように配置し, 4年一貫教育としての学部 課程の総合化を図る。

（3）学部の学科区分は，産業界の実情と工業技術の動 向に照らして適時に見直しを行うが，学部 4 年間の 前期では共通の基盤をもつ数個の学科を括って 「系」による学生編成を行い, 一般教育, 学部共通 の工学基礎教育と併せて系共通基礎の教育を行い, 適切な時期に学科分属を行って, 漸次専門性を強如 て最終段階では学科の専門基礎の教育に進むものと する。

（4）現在，全学科を，情報エレクトロニクス系，物理 
工学系, 材料・科学系, 社会工学系の 4 系に括るこ とを計画している。これによって, 同一系内の諸学 科の共通基盤をなす基礎知識を体得させるとともに, 各学科が対応する工学諸分野の社会的な立地と相互 関係, それぞれの技術領域構成の共通点と相違点等 の特性の概要を理解させ, 最終段階の学科教育では, 当該分野を構成する諸要素領域の専門基礎知識とそ れらを総合する手法を学ばせる。

\section{2 大学院の改革}

大学院に独自の組織機構を構築するに当り, 大学院 が教育研究の対象とする「工学」ならびに「工学専門 家」のあり方を次のように設定する。

一般的に, 工学を「目標とする機能を創出するため に構成すべき要素についてのあらゆる可能性を求め, 選択し, 総合し, 評価するための科学」であるとする。 大学院は最先端の研究者を含む高度の「指導的工学専 門家」の育成の場として, 教育と研究を統合的に展開 することを使命とする。このような工学専門家には, 幅広い工学基礎の知識の上に, 専門工学領域の高度の 能力を身につけることが求められる。この場合の専門 工学は,「創出すべき機能あるいは課題処理の方法」 を共有するという専門性により, 再構築される工学を 指向する。

新しい大学院は, その目的を十分に果たすために, 組織としてこれまで学部の学科の上に積み重ねられて いた専攻を, 上述の専門工学の新理念によって再編成 しなければならない。大学院工学研究科は, 工学部と は組織構成原理を異にするものとなり, 組織を分離し て大学院としての明確な構造を造る必要がある。また, 高度の指導的な工学専門家の養成という大学院の使命 を全うするためには, 新しい工学研究科を主体的な組 織として全体の教育研究機構を運営することが必要に なる。

新構想における研究科の組織は, 研究の対象とする 「機能」, あるいは研究の「方法」の共通性によって, 現在の $3 \sim 4$ の講座を従来の専攻の枠を超えて集約し て新しい教育研究の単位組織とし, これを「専修」と 呼ぶこととしている。各専修は, それぞれの専門領域 についての体系的なカリキュラムを提示する。これら の専修を専門基礎を共有する範囲で括って専攻を構成 し,これにより学生編成を行う。

学生には, 所属専攻の内の 1 専修を主専修と定めて, そこで研究指導を受けるとともに, 所属の專攻に関わ りなく他の専修を副専修として選択して, 主・副両専 修の提示するカリキュラムを併せて履修することを義
務付け，各教科目についての到達度を適正に評価する スクーリング重視の教育を行う。

この主・副専修を組合せて 1 つの履修課程に構成す る教育体制を「双峰型」と呼ぶことにしているが,こ れによって, 学生の学習関心に応じて極めて多様な履 修課程をデザインすることが可能であり, 学生は $2 つ$ の高度の専門工学領域の体系的な知識と研究方法を修 得し，それらを座標軸とする広角的な発想力をもつ工 学専門家として新しい課題に対処できるようになる。

本構想では, 工学研究科に最終的に 44 専修を設置す ることを目標とする計画案を策定しているが,この双 峰型の履修課程は, これらの広範な選択枝の中から 2 つの専門工学のカリキュラムを組み合せて 1 つの必修 課程として構成するもので, 従来の定型的な専攻の概 念を超える柔軟な機構であるとともに，通常の選択科 目制で個々の教科目を任意履修させる多様化とも異な り, 工学の教育研究の新たな展開の可能性を開くもの である。

\section{5.おわりに}

北海道大学工学部では, 昭和 59 年 5 月 14 日付の文部省 通知(文大大第184号)「国立大学等における組織及び運営 の見直しの実施について」を受けて, 工学の将来のあり 方について積極的な検討を進め, 昭和 61 年 5 月には工学 部教育研究機構調查会を設置して教育研究の現状の点検 評価を行って問題点を明らかにし, 将来に向けての工学 教育の理念を追求して, 組織機構の将来像を描き出した 改革の基本構想を昭和 62 年 12 月に報告書として取りまと めた。引き続き，機構改革特別委員会を設置して目標と すべき新しい教育研究機構の具体案を策定し, さらに平 成元年 4 月以降は改革推進委員会を設置して新教育研究 機構の実現を目指して必要な検討を続けている。本論で は，その将来構想の概要を紹介した。工学教育関係なら びに工業界の方々からご示唆，ご教示をいただき，より よく未来を見据えて前へ進むことができればまことに幸 いである。

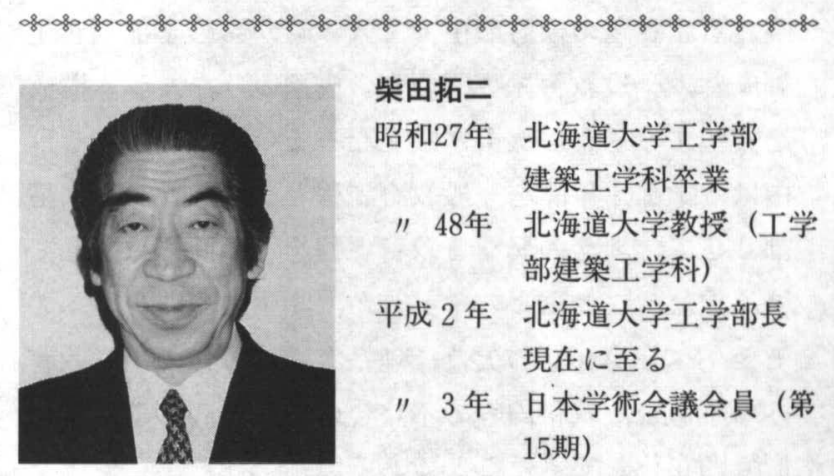

